\title{
Persoonsgerichte zorg en richtlijnen
}

Citation for published version (APA):

Burgers, J. (2017). Persoonsgerichte zorg en richtlijnen: contradictie of paradox? Maastricht University. https://doi.org/10.26481/spe.20170616jb

Document status and date:

Published: 16/06/2017

DOI:

10.26481/spe.20170616jb

Document Version:

Publisher's PDF, also known as Version of record

\section{Please check the document version of this publication:}

- A submitted manuscript is the version of the article upon submission and before peer-review. There can be important differences between the submitted version and the official published version of record.

People interested in the research are advised to contact the author for the final version of the publication, or visit the DOI to the publisher's website.

- The final author version and the galley proof are versions of the publication after peer review.

- The final published version features the final layout of the paper including the volume, issue and page numbers.

Link to publication

\footnotetext{
General rights rights.

- You may freely distribute the URL identifying the publication in the public portal. please follow below link for the End User Agreement:

www.umlib.nl/taverne-license

Take down policy

If you believe that this document breaches copyright please contact us at:

repository@maastrichtuniversity.nl

providing details and we will investigate your claim.
}

Copyright and moral rights for the publications made accessible in the public portal are retained by the authors and/or other copyright owners and it is a condition of accessing publications that users recognise and abide by the legal requirements associated with these

- Users may download and print one copy of any publication from the public portal for the purpose of private study or research.

- You may not further distribute the material or use it for any profit-making activity or commercial gain

If the publication is distributed under the terms of Article $25 \mathrm{fa}$ of the Dutch Copyright Act, indicated by the "Taverne" license above, 


\section{Persoonsgerichte zorg in richtlijnen: contradictie of paradox?}

Oratie Prof.dr. Jako Burgers, huisarts

16 JUNI 2017, MAASTRICHT

IM Maastricht University 
PERSOONSGERICHTE ZORG IN RICHTLIJNEN: CONTRADICTIE OF PARADOX? 



\section{Persoonsgerichte zorg in richtlijnen: contradictie of paradox?}

\section{Kernboodschappen}

- Persoonsgerichte zorg vraagt om gerichte toepassing van beschikbare kennis met richtlijnen als leidraad.

- Richtlijnen vormen een betrouwbare basis van de geneeskunde, mits samengesteld op basis van wetenschappelijke literatuur, breed gedragen professionele expertise en relevante patiëntervaringen.

- Richtlijnen ondersteunen het proces van klinische besluitvorming door de beleidsopties en afwegingen expliciet te maken voor de arts én de patiënt.

- Richtlijnen zijn er niet om blind opgevolgd te worden, maar om weloverwogen te gebruiken als hulpmiddel bij het leveren van persoonsgerichte zorg in de praktijk.

Mevrouw de rector magnificus, familie, vrienden, kennissen, collega's en andere belangstellenden,

Het is mij een groot genoegen $u$ hier te treffen. Fijn dat $u$ uit alle delen van het land hiernaartoe bent gereisd. Naar Maastricht, waar de jongste universiteit van Nederland is gevestigd, en waar sinds vorig jaar ook de jongste rector magnificus van Nederland is aangesteld. Daar zijn wij trots op!

Ik vind het een voorrecht om hier te mogen staan; in de aula van de universiteit die mij vanaf de eerste dag heeft geïnspireerd. Vanwege de onverschrokkenheid, het lef om heilige huisjes omver te werpen en om van gebaande paden af te wijken. De keuze voor een bordeauxrode in plaats van een zwarte toga getuigt hiervan. Het voelt goed, kan ik u verzekeren!

Met de titel van mijn rede wil ik $u$ aan het denken zetten. Persoonsgerichte zorg en richtlijnen? Dat kan toch niet samengaan? Richtlijnen bevatten algemene regels en staan persoonsgerichte zorg per definitie in de weg, zou u kunnen zeggen. Ik zal betogen dat richtlijnen nodig zijn om persoonsgerichte zorg mogelijk te maken. Persoonsgerichte zorg met een wetenschappelijke basis, binnen de context van de academische geneeskunde, welteverstaan. Hiertoe zal ik $\mathrm{u}$ meenemen op reis naar de kern van de wetenschappelijke uitoefening van mijn vak, de huisartsgeneeskunde. We maken tussenstops langs drie verschil- 
lende, zeer gewaardeerde bronnen van kennis (Figuur 1) - de bevindingen uit de wetenschappelijke literatuur (ook wel 'evidence' genoemd), de professionele expertise en de patiëntervaring - aangevuld met verhalen uit mijn eigen praktijk. Het einddoel van de reis is het leveren van persoonsgerichte zorg in de praktijk. Aan het eind van deze rede wil ik graag met $u$ de plannen voor onderzoek en onderwijs delen om persoonsgerichte zorg te bevorderen.

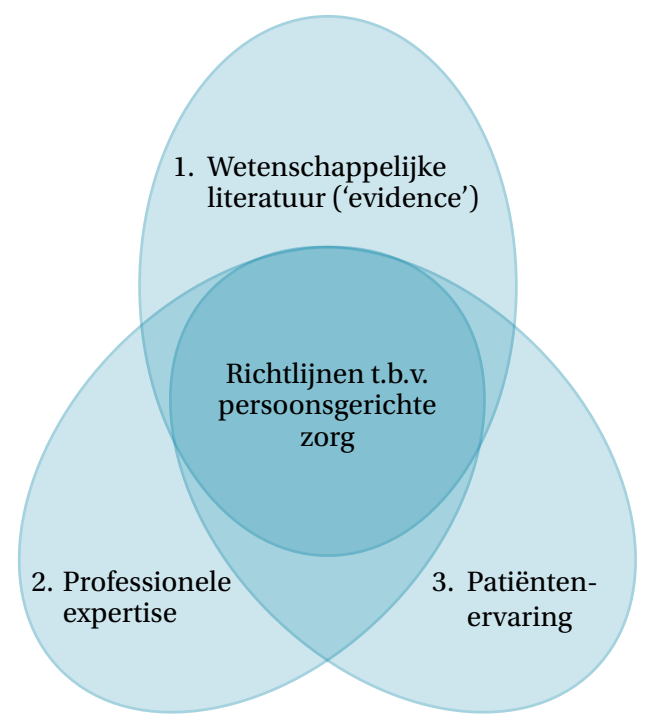

Figuur 1 Drie bronnen van kennis voor richtlijnen en persoonsgerichte zorg

\section{Voorbeeld uit de praktijk}

We beginnen onze reis met een voorbeeld uit mijn praktijk.

\section{Casus 1 Oudere vrouw met multimorbiditeit}

Mevrouw Schol is 84 jaar. Ik ken haar al sinds het begin van mijn praktijk in 1995. Ze heeft een schildklieraandoening, hoge bloeddruk, botontkalking, een langzaam toenemende nierfunctiestoornis, nachtelijk onrustige benen en ze slikt dagelijks acht verschillende medicijnen. Haar man is in 2005 overleden aan hartfalen. Mevrouw woont zelfstandig in een kleine seniorenwoning en heeft goed contact met haar kinderen en kleinkinderen, die in de buurt wonen.

In 2010 krijgt mevrouw Schol een beroerte. Ze herstelt hiervan met een gevoelsstoor- 
nis van haar rechterarm en -been als restverschijnsel. Daar heeft ze dagelijks veel last van. 'Maar ja, je kunt er toch niets aan doen,' zegt ze dan. 'Je moet ermee leren leven. Maar ik wil het af en toe wel aan u kwijt: het is heel erg irritant!' Bijkomend verschijnsel is dat de bloeddruk na haar beroerte is gaan stijgen. Samen proberen we deze te reguleren volgens de aanbevelingen uit de NHG-Standaard Cardiovasculair risicomanagement. Mevrouw Schol behoort tot een hoogrisicogroep en wil liever niet nog eens een beroerte doormaken. Het reguleren van haar bloeddruk gaat echter moeizaam. De ene pil geeft bijwerkingen, de andere heeft geen effect. We laten het er niet zomaar bij zitten, maar ook dosisverhogingen halen niets uit. De bloeddruk blijft hoger dan $180 \mathrm{mmHg}$, terwijl ze daar geen last van heeft. Wel blijft mevrouw Schol klagen over koude handen en voeten, terwijl de bètablokker, die deze bijwerking kan hebben, al lang gestopt is. We worden er samen moedeloos van.

Wat zou $\mathrm{u}$ doen als $\mathrm{u}$ haar arts was? Wat zou $\mathrm{u}$ willen als $\mathrm{u}$ mevrouw Schol was? Ik kom hier later op terug.

Als huisarts willen we goede, wetenschappelijk verantwoorde zorg leveren. Professionele richtlijnen dienen daarbij als leidraad en houvast. Maar als de streefwaarden van de richtlijn moeilijk zijn te realiseren en de patiënt de behandeling als ballast ervaart, wat is dan wijsheid? Toepassing van de 'academische' richtlijn lijkt persoonsgerichte zorg dan behoorlijk in de weg te staan.

Wat beogen we met richtlijnen te bereiken? Waarom zijn we er überhaupt mee begonnen, zou u zich kunnen afvragen. Ik zal dit toelichten aan de hand van een korte terugblik naar het ontstaan van richtlijnen in de geneeskunde.

\section{Historie van richtlijnen}

We gaan terug naar de Verenigde Staten in de jaren zeventig van de vorige eeuw. Daar werden op grote schaal gegevens verzameld over operaties en ingrepen in de verschillende regio's van het land (Wennberg, 1975). Het bleek dat er een enorme variatie bestond in hoe vaak bepaalde ingrepen werden uitgevoerd, zoals het verwijderen van amandelen, baarmoeder-, prostaat- en rugoperaties. In sommige staten werden operaties veel vaker uitgevoerd, terwijl de bevolking vergelijkbaar was en niet zieker werd geacht. De mening begon post te vatten dat naast medische redenen wellicht ook andere motieven een rol speelden om ingrepen uit te voeren. Dit was mede aanleiding tot een nationaal programma van consensusontwikkeling, de voorloper van richtlijnen, gefinancierd door de National 
Institute of Health (NIH) (Barclay, 1978). Een commissie van geleerden kwam gedurende een aantal dagen bij elkaar, werkte dag en nacht door en presenteerde vervolgens op de laatste ochtend aan de pers een document met aanbevelingen gebaseerd op consensus (van Everdingen, 1986).

Deze methode staat ook wel bekend als de GOBSAT-methode, oftewel 'the good old boys sat around the table' (Wollersheim, 2009). Of de artsen in het land zich iets van deze aanbevelingen aantrokken, is niet goed bekend. Maar de trend was wel gezet om gezamenlijk afspraken te maken over goede gezondheidszorg.

Het programma van de NIH stond model voor het CBO-consensusprogramma dat in de jaren tachtig in Nederland is ontstaan (Van Everdingen, 1988). Ook hierin werden richtlijnen gemaakt op basis van consensus. Maar omdat Nederland nu eenmaal een stuk makkelijker te bereizen is, werden de voorbereidingsbijeenkomsten van de commissie gespreid. En zo werd Utrecht het centrum van richtlijnenland Nederland.

In 1989 startte het Nederlands Huisartsen Genootschap met de ontwikkeling van de NHG-Standaarden (Thomas, 1993). Niet zozeer de praktijkvariatie, maar vooral de behoefte aan professionalisering van het vak ten overstaan van de medisch-specialisten, was de aanleiding voor het programma. Bij het ontwerp van het programma werd niet alleen aandacht besteed aan de ontwikkeling, maar ook aan de implementatie, oftewel de zorg voor het bevorderen van de daadwerkelijke toepassing van de richtlijnen in de praktijk (Grol, 1992a). Richtlijnen waren een nieuw fenomeen, dat ook op weerstand stuitte. Kookboekgeneeskunde of een keurslijf, vonden sommigen (Grol, 1992b). Maar deze groep vormde al snel een kleine minderheid. Na vier jaar werd het eerste boek met dertig standaarden gepubliceerd en drie jaar later volgden er nog eens dertig (Rutten, 1993; Thomas, 1996). Huisartsen waren verheugd over de herkenbare onderwerpen - urineweginfecties, keelpijn, bijholteontsteking, lagerugpijn, vaginale afscheiding - en het feit dat de beroepsgroep zelf aanbevelingen voor diagnostiek en therapie had geformuleerd. 'Richtlijnen door en voor huisartsen', zo heette de succesformule van het NHG.

In de jaren negentig van de vorige eeuw was er ook een andere beweging bepalend voor de uitstraling van de NHG-Standaarden: evidence-based medicine (EBM), oftewel op wetenschappelijk bewijs gebaseerde geneeskunde (Burgers, 1999; Scholten, 2014). Deze beweging ontstond in Canada als verzet tegen de gangbare opvattingen van de gevestigde orde van hoogleraren, de 
zogenoemde authority-based medicine (Sackett, 1997). EBM betekende een doorbraak naar het onafhankelijk nadenken (Grahame-Smith, 1995) en zette zelfs vraagtekens bij behandelingen die lange tijd onbetwist waren, zoals antibiotica bij oor- of bijholteontsteking. De kritische methode van EBM met de uitkomsten van systematisch literatuuronderzoek als basis voor het handelen, werd al snel door het NHG omarmd en vormt nog steeds de grondslag van onze richtlijnen (Van Everdingen, 2014). Op deze wijze zijn de NHG-Standaarden het wetenschappelijk robuuste fundament onder de huisartsgeneeskunde (Goudswaard, 2010).

Op onze reis maak ik nu graag met $\mathrm{u}$ een tussenstop bij de eerste bron van kennis: de evidence als grondslag voor richtlijnen.

\section{Evidence in richtlijnen}

De term evidence is lastig te vertalen en wordt vaak verkeerd begrepen. Een letterlijke vertaling is evidentie. In de wetenschapsfilosofie is dit het empirische materiaal - de gegevens die vanuit de werkelijkheid worden verzameld - waaraan men een hypothese toetst (Popper, 1959). Hiermee wordt de hypothese meer of minder aannemelijk gemaakt. Om de mate waarin dit het geval is te berekenen, is statistische toetsing vereist. Evidentie moet niet verward worden met bewijs, in het Engels proof. Dit is alleen van toepassing op logische stellingen in de wiskunde en de logica, de logische wetenschappen. Deze stellingen zijn niet toetsbaar, want ze kunnen alleen maar waar of niet waar zijn. Een hypothese uit de empirische wetenschappen, zoals de geneeskunde, daarentegen, kan nooit bewezen worden, maar wel aannemelijk worden gemaakt (Wiersma, 1999). Met de marge van onzekerheid die uit de statistische toetsing blijkt.

Een probleem in de geneeskunde, en in de huisartsgeneeskunde in het bijzonder, is dat er vele vragen zijn waarvoor maar weinig evidence beschikbaar is. Bijvoorbeeld op het gebied van alledaagse aandoeningen, zoals verkoudheid, nekklachten, oorsmeer en galbulten. Er gaan geen mensen aan dood en gelukkig gaan de meeste klachten vanzelf over, maar toch staan we met de mond vol tanden als men vraagt naar oorzaken en factoren die het beloop van de klacht kunnen beïnvloeden. Het betreft hiaten in kennis waar geen of weinig onderzoek naar is gedaan. Dat voor deze alledaagse aandoeningen inmiddels weer meer aandacht is, onder andere in het rapport van de Gezondheidsraad dat vorig jaar verscheen (Gezondheidsraad, 2016) en door de oprichting van de 
Stichting Fonds Alledaagse Ziekten, stemt hoopvol.

\section{Evidence-biased medicine}

Naast het gebrek aan evidence is er een ander probleem dat wellicht meer zorgen baart. Wetenschappelijk onderzoek komt niet tot stand zonder adequate financiering. Idealiter heeft de financierende organisatie geen invloed op de resultaten en wordt onderzoek belangeloos gesteund. Dit is echter niet vaak het geval. De geneeskunde is een markt waar mensen veel geld uitgeven en waar dus ook veel geld kan worden verdiend. Succesvolle innovaties, zowel op het gebied van diagnostiek als therapie, kunnen bedrijven miljarden opleveren. De druk om een klein effect uit te vergroten en krachtige marketingstrategieën in te zetten om innovaties ingevoerd te krijgen, is groot. Gepubliceerd wetenschappelijk onderzoek is een van de middelen om artsen en andere professionele zorgverleners te overtuigen. Zowel financiers als onderzoekers, die baat hebben bij zoveel mogelijk publicaties, hebben meer belang bij het publiceren van positieve dan negatieve resultaten, de zogenoemde publicatiebias. Wetenschappelijke literatuur is niet waardevrij en zit vol verborgen agenda's en verlangens. Deze hebben invloed op de onderzoeksagenda en op de uitkomsten van onderzoek. Evidence-based medicine wordt daarom, ietwat smalend, ook wel evidence-biased medicine genoemd (Every-Palmer, 2014).

Hoe wapenen wij ons hiertegen? Als voorvechters van het onafhankelijke wetenschapsbedrijf willen we niet overgeleverd worden aan de grillen van de markt. De Nederlandse gemeenschap van richtlijnmakers heeft dit probleem al vroeg erkend en zich verzameld in het EBRO-platform (Burgers, 2004a). Dit platform organiseerde jaarlijkse symposia rondom thema's als 'zorg voor evidence' (2005) en 'de invloed van de industrie' (2007). Later werd het platform omgedoopt tot GENEVER, dat tweejaarlijkse expertbijeenkomsten organiseert om elkaar bij te praten over recente ontwikkelingen op het gebied van de methodologie.

Internationaal groepeerden onderzoekers en richtlijnmakers zich in de AGREE Collaboration, dat in 2001 het AGREE Instrument publiceerde: een instrument om de kwaliteit van richtlijnen te beoordelen (AGREE Collaboration, 2003). Hieruit is het Guidelines Internationaal Netwerk (G-I-N) voortgekomen, met CBO en NHG als medeoprichters. Nu snapt u ook de knipoog in de naam van het Nederlandse netwerk. In dezelfde periode ontstond de GRADE working group, een groep van 'hardcore' methodologen, waar ook pioniers van de EBMbeweging aan deelnamen. Zij ontwierpen een systeem voor het graderen van 
evidence en recommendations (aanbevelingen), met veel aandacht voor alle mogelijke vormen van vertekening (bias) (Guyatt, 2008).

De criteria van het AGREE Instrument vormen de basis voor de leidraad voor kwaliteitsstandaarden van het Zorginstituut Nederland om te beoordelen of richtlijnen volgens de regels der wetenschap zijn opgesteld en dat het kaf van het koren tracht te scheiden (AQUA, 2015). Het GRADE systeem is inmiddels wereldwijd het meest gebruikte systeem om evidence adequaat en onafhankelijk te beoordelen en samen te vatten. Het is echter zo complex geworden dat alleen geschoolde richtlijnmethodologen het nog goed kunnen uitvoeren. 'The good old boys around the table' zijn vervangen door een gemêleerde werkgroep van wijze mannen en vrouwen, oud en jong, een mix van clinici, ervaringsdeskundigen en methodologen. De juiste balans in de richtlijnwerkgroep is het beste wapen tegen verleiding, vertekening en belangenverstrengeling (Fretheim, 2006). Zo schrijdt de wetenschap in richtlijnen voort op zoek naar een gemeenschappelijke visie.

Hiermee zijn we aangekomen bij de tweede tussenstop van onze reis, de professionele expertise als bron van kennis.

\section{Professionele expertise als bron van kennis}

Expertise kan worden omschreven als kennis en ervaring op een specifiek terrein. Binnen de geneeskunde wordt expertise opgebouwd door gedurende vele jaren veel individuele en bijzondere gevallen te zien, waardoor patronen worden herkend en geduid. Expertise komt deels tot stand door analyse en begrip via gangbare leermethoden, maar bestaat voor een ander deel uit zogenoemde 'tacit knowledge', die meer intuïtief, impliciet en moeilijker overdraagbaar is (Polanyi, 1966). In de huisartsgeneeskunde wordt dit herkend als het pluis/ niet-pluisgevoel (Stolper, 2010). Na anamnese en onderzoek is het vaak nog steeds onduidelijk wat de patiënt mankeert; het pluis/niet-pluisgevoel geeft dan richting aan de beleidskeuze om af te wachten dan wel verder onderzoek of behandeling in te zetten. Deze bron van kennis is niet alleen in de praktijk onmisbaar, maar ook bij de totstandkoming van richtlijnen. De jarenlange ervaring van professionals met specifieke patiëntengroepen compenseren de vaak onvolledige of tegenstrijdige bevindingen uit wetenschappelijk onderzoek, zodat er toch verstandige aanbevelingen kunnen worden geformuleerd. 
Het is een groot misverstand dat richtlijnen de professionele expertise laag waarderen. Zonder deze specifieke bron van kennis en zonder het professionele draagvlak kunnen er geen praktisch toepasbare richtlijnen tot stand komen (Burgers, 2004b; Zuiderent-Jerak, 2012). De verklaring voor dit misverstand is dat de waarde van de aanbevelingen wordt verward met het niveau van bewijsvoering - de 'levels of evidence' - zoals ook door de eerdergenoemde GRADE working groep is ontwikkeld (Guyatt, 2008). Hierin wordt 'expert opinion' als laagste niveau van bewijs beschouwd en de systematische reviews van gerandomiseerd gecontroleerd onderzoek als hoogste. Toch kunnen bij gebrek aan bewijsmateriaal krachtige aanbevelingen worden geformuleerd op basis van praktijkkennis en ervaring (Wiersma, 2002). Zeker als de leden van de beroepsgroep het daar met z'n allen over eens zijn. Gedeelde uitgangspunten en opvattingen, zoals de adagia 'in dubio abstine' (bij twijfel niets doen) en 'primum non nocere' (in ieder geval geen kwaad doen), kunnen het beleid extra ondersteunen.

\section{Consensus in richtlijnen}

Het op een verantwoorde wijze verkrijgen van breed gedragen consensus maakt deel uit van de methode van evidence-based richtlijnontwikkeling. Want richtlijnen die niet kunnen rekenen op draagvlak, maken in de praktijk geen schijn van kans (Raine, 2005). Dit brengt wel nieuwe gevaren met zich mee. Hoe komt consensus tot stand? Wie het hardst roept, heeft gelijk? Ook hier zijn de samenstelling van de werkgroep en de wijze waarop deze wordt voorgezeten en begeleid van groot belang (Pagliari, 2001). Samen met de gedragscode dat deelnemers openheid geven over hun belangen, bereid zijn naar elkaar te luisteren en discussiëren op basis van argumenten (KNAW, 2012). De ervaring leert dat vrij snel duidelijk wordt wie stokpaardjes berijdt of de groep probeert te domineren met een eigen agenda. In dat geval treedt het groepsproces corrigerend op. In verreweg de meeste gevallen lukt het zo om tot consensus te komen.

We komen dichter bij het einddoel van onze reis, het leveren van persoonsgerichte zorg in de praktijk, en bereiken de derde belangrijke bron van kennis: de patiëntervaring of inbreng van de patiënt. Onmisbaar voor het leveren van persoonsgerichte zorg, maar ook bij de ontwikkeling van richtlijnen. 


\section{Patiëntervaring als bron van kennis}

Dé patiënt bestaat niet, wordt vaak gezegd, want elke patiënt is uniek. Dat klopt. En toch zijn er grote gemene delers en kan het proces waarop de patiëntervaring wordt ingezet in de besluitvorming wetenschappelijk worden benaderd. Dat wil zeggen: onderbouwd met systematisch verzamelde onderzoekgegevens (Légaré, 2011). Voordat ik hier verder op inga, zou ik graag de patiëntervaring willen illustreren aan de hand van een voorbeeld uit de praktijk. Dit voorbeeld laat ook zien hoe de toepassing van richtlijnen in de praktijk kan werken.

\section{Casus 2 Kind met oorpijn}

Ik heb avonddienst op de huisartsenpost in mijn regio. Om 23.0o uur zie ik Anne (3 jaar) op het spreekuur. Haar moeder vertelt dat Anne huilend wakker was geworden vanwege pijn, waarbij ze naar het rechteroor greep. De avond daarvoor was dat ook het geval geweest. Toen had moeder paracetamol gegeven. Na een uur was de pijn afgezakt en was Anne weer rustig gaan slapen. Overdag was ze weer speels. Deze avond had ze weer dezelfde oorpijn, maar ook koorts: $39,4^{\circ} \mathrm{C}$.

Anne komt slapend op de arm van haar moeder de spreekkamer binnen. Haar vader is er ook bij. Moeder vertelt dat zij zich zorgen begint te maken, omdat zij haar dochter suffer vindt dan de avond tevoren. Bij lichamelijk onderzoek vind $i k$ een rood en gespannen trommelvlies. Ik leg aan de ouders uit dat Anne een oorontsteking heeft en dat dit de pijn en koorts verklaart. Ook leg ik uit dat de behandeling bestaat uit paracetamol tegen de pijn en dat in de meeste gevallen de ergste pijn binnen twee tot drie dagen overgaat. De vader vraagt vervolgens: 'Dus u geeft geen antibiotica?'

Ik leg uit dat het genezende effect van antibiotica bij oorontsteking beperkt is. De eerste 24 uur is er geen effect te merken, maar daarna - van dag twee tot zeven bestaat er een kans van een op twintig dat het kind minder pijn gaat ervaren ten opzichte van afwachten zonder antibiotica. Daarbij bestaat er een kans van een op veertien dat ze bijwerkingen van de antibiotica zou kunnen ervaren, zoals overgeven, diarree of huiduitslag.' De vader brengt in: 'Een jaar geleden had Anne oorpijn en toen kreeg ze van de dienstdoende huisarts wel antibiotica. Daar is ze toen snel van opgeknapt.' Ik leg uit dat het effect van antibiotica bij kinderen jonger dan twee jaar groter is gebleken dan bij kinderen ouder dan twee jaar, dus dat bij jongere kinderen de balans vaak doorslaat ten gunste van antibiotica.' 'Maar mijn kind is zes weken te vroeg geboren en kwetsbaarder dan andere kinderen,' aldus vader. ' $k$ vind het toch prettig dat ze ook nu weer antibiotica krijgt.' Moeder vult aan: 'Ja, ik geloof dat ik me er rustiger onder voel als ze antibiotica krijgt. Voor bijwerkingen ben ik niet zo bang, want de vorige keer verdroeg ze de antibiotica ook goed.' Op 
basis van de afwegingen van de ouders schrijf ik antibiotica voor en zeg erbij dat de ouders ook kunnen wachten met het starten van de kuur en dat ze de kuur niet hoeven te starten, mocht het beter met Anne gaan. Wat ik heb verteld, kunnen ze nog eens rustig nalezen op Thuisarts.nl (Figuur 2).

\section{$\mathrm{A}|\mathrm{B}| \mathrm{C}|\mathrm{D}| \mathrm{F}$}

\section{Mijn kind heeft een}

middenoorontsteking

Onderwerp Middenoorontsteking

Synoniemen Otitis media acuta

\begin{tabular}{l} 
i= In het kort \\
\hline$\square$ Beschrijving \\
\hline Verschijnselen \\
\hline Medicijnen \\
\hline Hoe gaat het verder? \\
\hline Wanneer contact? \\
\hline Meer informatie?
\end{tabular}

Keuzehulp
$=$ In het kort

Een middenoorontsteking kan veel pijn doen

- Zorg voor goede pijnstilling met 4 maal per dag

paracetamol.

Helpt dat niet, overleg dan met uw huisarts of u ibuprofen kunt geven.

De pijn kan opeens verdwijnen. Het trommelvlies is dan gescheurd.

Er kan dan ontstekingsvocht uit het oor komen. Dit heet een loopoor.

- Soms zit daar wat bloed bij. Dat is niet erg.

Meestal zijn de ergste klachten binnen 2 tot 3 dagen over en geneest alles vanzelf.
Meer onderwerpen

Loopoor

Slijmoor

Koorts bij kinderen

Oorpijn

Trommelvliesbuisjes

\section{Wat is een middenoorontsteking?}

Het middenoor is de ruimte direct achter het trommelvlies. Tussen het middenoor en de neus-keelholte loopt een gangetje, de buis van Eustachius. Vocht uit het middenoor kan via dat gangetje naar de neus-keelholte.

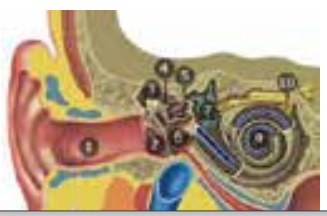

\section{Figuur 2 Fragment patiëntinformatie op Thuisarts.nl}

Deze casus illustreert de toepassing van richtlijnen in de praktijk, maar ook de gerechtvaardigde afwijking ervan op basis van gezamenlijke besluitvorming. De 
patiënt en ouders hebben een eerdere ervaring, het gaat om een kind dat gezien de leeftijd nog relatief kwetsbaar is en de ouders aanvaarden de mogelijke nadelen van de behandeling. Zo kan het gaan in de praktijk (Van Esch, 2016). Uiteraard is dit geen vrijbrief om meer antibiotica voor te schrijven onder druk van de patiënt. Maar wees eerlijk, dit zijn toch geen onredelijke patiënten of ouders? Samen met de huisarts komen zij weloverwogen tot een gedeeld besluit. Een voorbeeld van de tango in de spreekkamer (Van der Weijden, 2010).

\section{Demand-based medicine}

In een volgende casus die ik u wil voorleggen is de druk van de patiënt voelbaar en pertinent. Als ik er niet aan toegeef, zou de vertrouwensrelatie wellicht onder druk komen te staan.

\section{Casus 3 Man met rugpijn}

De heer Van Berk, 36 jaar, ken ik nauwelijks. Twee jaar geleden heb ik hem voor het laatst gezien in verband met een snijwond. Hij klaagt over pijn in de rug, die vier weken geleden plots is ontstaan na een verkeerde beweging bij het golfen. Er is geen uitstralende pijn naar de benen. Hij is zelfstandig naar een fysiotherapeut en osteopaat gegaan, maar beiden konden de pijn niet verhelpen. Hij bezoekt nu mijn spreekuur, want hij wil een MRI-scan om te weten wat er aan de hand is en of er iets verschoven is.

Ik onderzoek meneer en vind een rechte rug, een normale beweeglijkheid, geen kloppijn op de wervels en geen aanwijzingen voor een rughernia. Terug in de spreekkamer geef ik aan dat ik begrijp dat het vervelend is dat de pijn al vier weken duurt en dat er geen verbetering is opgetreden. Ik leg uit dat ik bij het onderzoek geen duidelijke afwijkingen heb kunnen constateren, maar dat dit bij rugpijn meestal het geval is. De patiënt onderbreekt mij en zegt dat hij toch een MRI-scan wil, want daar kun je meer op zien. Zijn golfvriend is onlangs in Duitsland geopereerd en toen dacht de huisarts eerst ook dat er niets aan de hand was. Ikzeg dat zijn klacht en het plotse begin na een beweging duiden op een verrekte spier en dat het vermoedelijk met bewegen en eventueel extra oefeningen over zal gaan. De patiënt houdt aan: 'Maar toch wil ik een MRI en als u hier niet voor zorgt, ga ik het zelf wel regelen.'

Daar zit je dan als huisarts met je richtlijnkennis en je professionele ervaring die heeft geleerd dat er ook veel ellende kan komen van rugoperaties op onjuiste indicatie. Ik leg aan de heer Van Berk uit dat ik als huisarts in onze regio geen MRI kan aanvragen en verwijs hem naar een orthopedisch chirurg die dat wel kan.

Een maand later ontvang ik de brief van de orthopedisch chirurg: 'Sinds een week gaat het beter. De scan toont geen fracturen en geen aanwijzingen voor een hernia of wervelkanaalstenose. Patiënt werd uit controle ontslagen.' 
Voor de huisartsen in de zaal: herkent $u$ dit ook uit uw praktijk? Dat onaangename gevoel dat je iets moet doen waar je niet achter staat? De patiënt krijgt weliswaar zijn zin, maar zou kunnen terugkijken op een consult waarin de huisarts hem niet serieus nam. De huisarts denkt: zie je wel, de klachten zijn vanzelf overgegaan, daar was geen scan voor nodig. Gelukkig leven we in Nederland, en niet in België, Frankrijk of Duitsland. Onze patiënten staan ingeschreven bij één huisartsenpraktijk en zijn doorgaans honkvast, ook als de patiënt een keer niet krijgt wat hij of zij verwacht. Ik ben benieuwd naar het volgende contact met de heer Van Berk en ben dan van plan nog even terug te komen op het vorige consult. Zou hij bij een volgende keer weer een scan willen? Binnen een bestendige vertrouwensrelatie zou dat misschien wel eens anders kunnen zijn.

Zo proberen we rekening te houden met het patiëntperspectief, maar niet ongelimiteerd. Anders ontaardt het in wat ik zou willen noemen 'demand-based medicine'. Dat is niet wenselijk, voor de individuele patiënt noch voor de maatschappij, waarin de zorg voor het grootste deel vanuit het collectief en op basis van solidariteit wordt gefinancierd. Het is daarom belangrijk patiënten te leren wat zij van de zorg kunnen verwachten, op basis van de twee eerdergenoemde kennisbronnen -evidence en professionele expertise - ook al stuit dat soms op verzet. Vanuit de continue relatie met de patiënt kan de huisarts daar bij uitstek aan bijdragen. De weg naar persoonsgerichte zorg betekent investeren in de relatie en, zoals dat met alle relaties gaat, kom je onderweg vrijwel altijd hobbels tegen. De Nederlandse huisarts heeft aangetoond hier uitstekend mee om te gaan gezien de langdurige relatie met de meeste patiënten.

\section{Patiëntparticipatie bij richtlijnen}

Niet alleen in de spreekkamer houden we rekening met de patiëntervaring, maar ook bij de ontwikkeling van richtlijnen. Op verschillende wijzen kan het patiëntperspectief worden ingebracht (Boivin, 2010). De laatste jaren gaat dit steeds meer in overleg met de landelijke patiëntorganisaties en de koepels daarvan, zoals de Patiëntenfederatie Nederland en het Platform GGz, met het Zorginstituut Nederland als aanjager (De Booys, 2015). Als er een representatieve landelijke patiëntenorganisatie bestaat, wordt deze benaderd om input te geven in verschillende fasen van het ontwikkelingsproces. Deelname aan de werkgroep lijkt aantrekkelijk, maar vereist behoorlijk veel training en vaardigheden om de discussies in de werkgroep goed te kunnen volgen en een eigen geluid in te brengen (Diaz Del Campo, 2011). Bij onderwerpen zoals diabetes mellitus, borstkanker, cardiovasculair risicomanagement en astma/COPD zijn er goede patiëntvertegenwoordigers beschikbaar, maar voor andere, kleine on- 
derwerpen in de huisartsgeneeskunde zijn deze moeilijk te vinden. Een alternatief is het organiseren van focusgroepen waarin de meningen van circa tien patiënten met de aandoening of kwaal met uiteenlopende achtergronden input kunnen geven. Het NHG heeft de laatste jaren van deze methode al diverse malen dankbaar gebruikgemaakt.

Naarmate er meer belangen op het spel staan, wordt de noodzaak om het patiëntperspectief gecontroleerd en reproduceerbaar in te zetten groter. Dit is een wetenschap op zich geworden waar al diverse onderzoekers op zijn gepromoveerd (Van de Bovenkamp, 2010; Boivin, 2012). Kenmerkend is de mix van het hanteren van kwantitatieve en kwalitatieve methoden. Naast de 'evidence' heeft een narratieve benadering toegevoegde waarde (Greenhalgh, 1999). Patientverhalen leren ons veel over het zorgproces en over wat patiënten belangrijk vinden. Zo komt de meerwaarde van het patiëntperspectief vooral aan het licht als het gaat om de waarde en betekenis van klachten en ervaringen in de zorg. Deze zijn soms aanzienlijk anders dan wat zorgverleners verwachten. Reumapatiënten willen zich vooral minder vermoeid voelen en zijn niet zozeer uit op extra pijnstilling (De Wit, 2013), diabetespatiënten willen vooral geen hypo krijgen en zijn minder bang voor een wat hoger HbAlc, en chronische longpatiënten hechten meer waarde aan het vermogen om nog zelfstandig boodschappen te kunnen doen dan aan de longfunctiewaarden. Deze voorkeuren kunnen worden gebruikt bij het literatuuronderzoek en bij het opstellen van aanbevelingen en keuzehulpen (Van der Weijden, 2013). Uiteraard zijn er binnen patiëntengroepen ook verschillen in wensen en voorkeuren die niet allemaal in een richtlijn kunnen worden beschreven. In de praktijk blijft het devies om deze steeds in het contact met de individuele patiënt na te gaan.

Dit brengt mij terug naar de casus van mevrouw Schol. Hoe is het met haar verdergegaan? Heeft $\mathrm{u}$ bedacht wat $\mathrm{u}$ zou doen of willen?

\section{Casus 1 (vervolg) Oudere vrouw met multimorbiditeit}

Het lukte maar niet om de bloeddruk goed omlaag te krijgen. Hoe nu verder? Samen besloten wij om de internist te raadplegen bij wie ze vanwege haar nierfunctiestoornis al bekend was.

Na een paar weken krijg ik een briefvan de internist met het volgende bericht: 'Patiënte krijgt steeds bijwerkingen bij nieuwe antihypertensiva. Daarom heb ik in overleg met patiënte besloten om het bij enalapril te houden en de bloeddruk verder niet meer te meten. Tenslotte is hypertensie geen ziekte, maar een risicofactor. Bij het optimaal reguleren van de bloeddruk verlaag je het risico op een hartinfarct 
of beroerte met 30\%. Dat moet je bij oudere mensen afwegen tegen het risico van te sterke bloeddrukdalingen met duizeligheidsklachten tot gevolg. Bij haar 24-uurs bloeddrukmeting waren ook heel lage waarden aanwezig. Patiënte werd van verdere poliklinische controles ontslagen en mijn advies aan u is om de bloeddruk niet meer te controleren.'

Ikzie mevrouw Schol een week later op mijn spreekuur, lachend en ontspannen. 'Dokter, weet $u$, ik ben zo blij dat mijn bloeddruk niet meer hoeft te worden gemeten. Ik heb nu zoveel meer rust in mijn lijf. Ook al zou het hoog zijn, het kan mij niet schelen. Ik voel me zo veel beter, dan ga ik maar een jaartje eerder. Maar liever dat dan weer extra medicijnen.'

Richtlijnen zijn een groot goed en onmisbaar voor de praktijk, omdat zij de arts snel van de juiste informatie kunnen voorzien. Bovendien zorgen de richtlijnen voor betrouwbare voorlichting via de voor de patiënt toegankelijk gemaakte informatie op Thuisarts.nl. Maar ook deze casus illustreert hoe gemotiveerd kan worden afgeweken van de richtlijn. De ervaringen van de patiënt met de ingestelde behandelingen hebben het beleid bepaald en daarnaast de arts die op basis van zijn professionele expertise samen met de patiënt de afwegingen maakt. Persoonsgerichte zorg in optima forma, maar wel mét en niet zónder de richtlijnen (Burgers, 2015).

\section{Aandacht voor persoonsgerichte zorg}

De toenemende aandacht voor persoonsgerichte zorg kan gezien worden als een reactie op de overheersende rol van richtlijnen in de zorg, die vooral zichtbaar wordt door het monitoren van de toepassing daarvan in de praktijk (Greenhalgh, 2014). Niet alleen door zorgverzekeraars, maar ook door zorginstellingen die de wet- en regelgeving met betrekking tot kwaliteit en veiligheid moeten volgen. De evaluatie van het gebruik van richtlijnen in de praktijk is essentieel om de kwaliteit van zorg te waarborgen. Het is echter buitengewoon lastig gebleken om betrouwbare indicatoren op te stellen die echt iets zeggen over goede zorg. De casus van mevrouw Schol laat zien dat het behalen van de bloeddrukstreefwaarde eerder duidt op slechte dan op goede zorg, want mevrouw zou er doodongelukkig van worden en er minder kwaliteit van leven door ervaren. Ook de streefwaarden van cholesterol en diabetesinstelling gaan soms een eigen leven leiden, waarbij men de persoon van de patiënt uit het oog verliest. Dit trekken wij ons als huisartsen die persoonsgerichte zorg als kernwaarde van het vak beschouwen aan (Huygen, 1959). 


\section{Kernwaarden van de huisartsgeneeskunde}

- Generalistisch: voor alle mensen en voor alle klachten

- Continu: toegankelijk en beschikbaar

- Persoonsgericht: op de mens in eigen woon-, werk- en leefomgeving

\section{Persoonsgerichte zorg in richtlijnen: een paradox}

Persoonsgerichte zorg en richtlijnen lijken op het eerste gezicht niet samen te kunnen gaan (Damoiseaux, 2014). Ik ben van mening dat dit bij een verantwoorde toepassing wel kan. Er is geen sprake van een contradictie (tegenstelling), maar van een paradox (een schijnbare tegenstelling). De richtlijn bepaalt niet wat goede zorg voor de patiënt is, maar de huisarts en de patiënt bepalen dat samen. De huisarts bereidt zich voor door kennis te hebben van de richtlijn en de patiënt bereidt zich voor door de juiste vragen te stellen (Figuur 3).

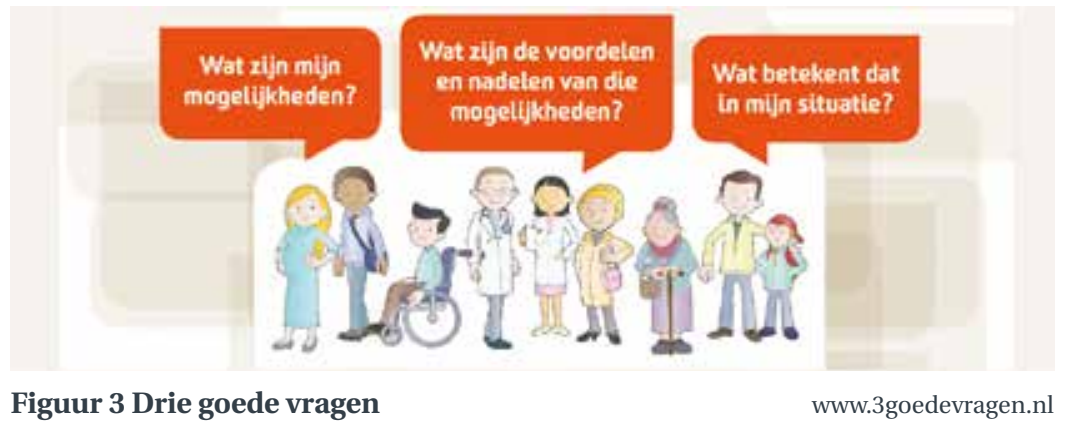

Zo komt er een dialoog tot stand die richting geeft aan het beleid. Door richtlijnen meer toe te rusten met keuzehulpen waarbij uit gelijkwaardige opties kan worden gekozen, krijgt de inbreng van de patiënt meer gewicht en wordt persoonsgerichte zorg bevorderd (Van der Weijden, 2012). Richtlijnmakers als het NHG, het Zorginstituut Nederland en het Kennisinstituut van Medisch Specialisten zijn hier de laatste jaren druk mee bezig in samenwerking met de Patiëntenfederatie Nederland. Dit heeft onder andere geleid tot de Leidraad voor ontwikkelen van patiënteninformatie en keuzehulpen (Zorginstituut Nederland, 2016) en de zogenoemde consultkaarten, een nieuwe keuzehulp voor patiënten en artsen (consultkaart.nl). Een boeiende ontwikkeling die uiteraard niet zonder hobbels verloopt, maar wel met de ambitie om gezamenlijk de zorg beter en inzichtelijker te maken. 
Ter afsluiting van onze reis zou ik nu graag met $\mathrm{u}$ een blik willen werpen op mijn plannen voor het onderzoek en onderwijs dat gekoppeld is aan deze leerstoel, met het bevorderen van persoonsgerichte zorg in richtlijnen als leeropdracht.

\section{Onderzoek}

Deze leerstoel is een initiatief van het NHG en sluit aan op de missie om een wetenschappelijk gefundeerde uitoefening van de huisartsgeneeskunde in de praktijk te bevorderen. Het onderzoek binnen deze leerstoel is gericht is op de praktijk van alledag, waarin besluitvorming op basis van kennis en toepassing van de NHG-Standaarden een belangrijke rol spelen.

De leerstoel is ondergebracht binnen CAPHRI, dat staat voor Care Public Health Research Institute, binnen het programma Promoting Health and Personalised Care. Het thema van de leerstoel sluit goed aan bij alle ontwikkelingen op het gebied van personalised medicine. Hierbij gaat het om het preciezer in kaart brengen van genetische, familiaire en andere persoonlijke kenmerken, waardoor er beter voorspellingen gedaan kunnen worden over de risico's op het krijgen van bepaalde ziekten of complicaties van ziekten. Het wordt daarom ook wel 'precision medicine' genoemd (National Research Council, 2011). Personalised care - persoonsgerichte zorg - kan worden beschouwd als de praktische uitoefening van personalised medicine, waarbij naast de verzamelde biologische gegevens ook nadrukkelijk wordt gevraagd naar de persoonlijke doelen van de patiënt in diens eigen woon-, werk- en leefomgeving (Berntsen, 2015).

Bij de verbinding van 'medicine' en 'care' kunnen richtlijnen een rol spelen. Hoe dat het best kan gebeuren, is onderwerp van onderzoek. Centraal staat de vraag in welke mate richtlijnen kunnen helpen bij de besluitvorming om effectieve persoonsgerichte zorg te leveren. Niet alleen de richtlijn zelf, maar ook hulpmiddelen bij de toepassing, zoals stroomdiagrammen, keuzehulpen en elektronische applicaties, kunnen op hun effectiviteit worden onderzocht. In het voorbeeld van mevrouw Schol zouden de voor- en nadelen van het intensiveren van de behandeling met geneesmiddelen in een handzaam overzicht kunnen worden vermeld.

De effecten van het gebruik van richtlijnen en keuzehulpen op de individuele patiëntenzorg en patiënttevredenheid wil ik graag onderzoeken. Maar ook op regionaal of nationaal niveau kan onderzoek worden gedaan, bijvoorbeeld naar de invloed van richtlijnen op het terugdringen van onnodig aanvullend onderzoek (laboratorium en beeldvormend), het voorschrijven van antibiotica, 
psychofarmaca en merkgeneesmiddelen, en verwijzingen naar de tweede lijn. Ook ben ik zeer benieuwd naar de effecten van spiegelinformatie of feedback op basis van richtlijnen, met bespreking in lokale samenwerkingsverbanden.

Het doet mij deugd dat ZonMw zich hard maakt om meer onderzoek in de eerste lijn te stimuleren binnen programma's als Goed Gebruik Geneesmiddelen, Antibiotica Resistentie en Doelmatigheidsonderzoek. Genoeg kansen, zou je zeggen!

\section{Onderwijs}

EBM is oorspronkelijk ontwikkeld als onderwijsmethode met als doel de geneeskundige kennis zoveel mogelijk te onderbouwen met onderzoekgegevens en niet (alleen) te vertrouwen op oordelen van autoriteiten. Het zoeken naar literatuur en het kritisch beoordelen daarvan zijn basisvaardigheden die zowel in de opleiding tot arts als in elke vervolgopleiding worden geleerd.

Het onderwijs over evidence-based medicine (EBM) is onderdeel van de bacheloropleidingen geneeskunde en gezondheidswetenschappen. Veel aandacht gaat uit naar de beoordeling van de kwaliteit van de verschillende typen wetenschappelijk onderzoek (denk aan RCTs, diagnostisch onderzoek, prognostisch onderzoek en systematische reviews). Deze beoordeling is echter steeds complexer geworden en in de praktijk voorbehouden aan methodologen. Mijn uitdaging is om vooral aandacht te geven aan de beoordeling van richtlijnen, aan de wijze waarop deze de kennis proberen samen te vatten en aan de flexibele, persoonsgerichte toepassing van richtlijnen in de praktijk. Om persoonsgerichte zorg te leveren zijn vaardigheden nodig om de wensen, voorkeuren en verwachtingen van de patiënt inzichtelijk te maken en om risico's en onzekerheden op een begrijpelijke manier uit te leggen aan de patiënt. Dit zou in mijn ogen onderdeel moeten zijn van elke beroepsopleiding in de gezondheidszorg.

Tot slot zou ik als onderdeel van het NHG-wetenschapsbeleid graag de samenwerking met de afdelingen Huisartsgeneeskunde willen voortzetten om de wetenschappelijke opleiding tot huisarts verder te stimuleren. Huisartsen in opleiding kunnen bijdragen aan de beantwoording van zoekvragen voor een NHG-Richtlijn. Ook kunnen wetenschappelijke stages bij het NHG mogelijk gemaakt worden. Niet alleen door bij te dragen aan het literatuuronderzoek, maar ook door het proces van richtlijnontwikkeling in bredere zin te volgen. Het NHG is een fantastische leeromgeving voor jonge, enthousiaste collega's. 


\section{Dankwoord}

Ik ben nu aan het einde gekomen van mijn rede en wil tot slot graag een woord van dank uitspreken.

Allereerst dank ik de rector en het college van bestuur voor het in mij gestelde vertrouwen. In het bijzonder dank ik Nanne de Vries, vicedecaan. Ons kennismakingsgesprek heb ik als een warm welkom ervaren.

Veel dank ben ik verschuldigd aan Trudy van der Weijden, vice voorzitter van het programma Promoting Health \& Personalised Care. Jij hebt mij overgehaald om de NHG-leerstoel in Maastricht onder te brengen. De reistijd wordt ruimschoots goed gemaakt door de werkvreugde die ik hier beleef, mede dankzij jouw enthousiasme en persoonlijke aandacht.

Ik dank Maurice Zeegers, directeur van CAPHRI, voor zijn steun voor deze leerstoel, alsmede Job Metsemaker en Jean Muris, voormalig respectievelijk huidig voorzitter van de vakgroep Huisartsgeneeskunde. Ik vind het een voorrecht om deel uit te maken van het topteam van senioren.

Ik waardeer de bestuursvoorzitter van het NHG, Rob Dijkstra, voor zijn steun en vertrouwen. Op ons eerste werkoverleg opperde jij reeds de mogelijkheid van de NHG-leerstoel. Dank voor de vrijheid die je mij bood om deze vorm te geven binnen het NHG-wetenschapsbeleid. Ook dank ik de leden en voormalig leden van het managementteam, in het bijzonder Ivo Smeele en Marc Eijck, tevens collega-huisartsen. Jullie zijn en blijven mijn beste maten, door dik en dun.

Dank ook aan alle huisartshoogleraren, verenigd in het Interfacultair Overleg Huisartsgeneeskunde ( $\mathrm{IOH})$, voor de steun aan het NHG-wetenschapsbeleid en deze leerstoel. Jullie zijn het neusje van de zalm, nationaal en internationaal. Ik vind het een voorrecht om met jullie te mogen samenwerken.

Alle medewerkers van de afdeling Richtlijnontwikkeling en Wetenschap dank ik voor de hechte samenwerking in de afgelopen jaren. De groei die we samen hebben doorgemaakt, hebben we te danken doordat we problemen niet uit de weg gaan en uitdagingen opportunistisch aanpakken. Jullie zijn een fantastisch team binnen het NHG. 
Graag wil ik Hetty Papendorp, mijn persoonsgerichte en persoonlijke assistente, bijzonder bedanken voor alle ondersteuning, ook bij de voorbereiding van deze dag. Het is een enorme luxe om jou aan mijn zijde te hebben. Ook Mariëtte Henkes en Yvon Jonkers vanuit het NHG-evenemententeam en Babette Doorn, Ine Siegelaer en Karin Vaessen vanuit CAPHRI ben ik erkentelijk voor hun extra inzet voor de organisatie van deze dag.

Veel heb ik geleerd van Richard Grol en Niek Klazinga, mijn promotoren. Richard, dank voor de inspiratie en begeleiding tijdens mijn loopbaan, met het Harkness fellowship als sleutel op weg naar deze leerstoel. Niek, ook jij hebt hier in belangrijke mate aan bijgedragen.

Woorden van bijzondere dank verdienen Lex Goudswaard en Siep Thomas. Lex, collega, fietsmaat maar bovenal vriend, dank voor het luisterend oor en je scherpe analytische blik. Ik hecht veel waarde aan jouw mening. Siep, jij bent mijn eerste leermeester. Samen met Frans Meulenberg vormde jij in de jaren negentig een koningskoppel bij het NHG. Dank voor al jouw wijze lessen en voor de open en directe feedback die je me gegeven hebt. Dat geldt onverminderd voor Frans die weer een vaste plek in de Domus Medica heeft gevonden.

Ook al is de oratie een persoonlijk verhaal, anders dan een richtlijn, zonder meelezers en kritisch commentaar is de totstandkoming ondenkbaar. Naast een aantal eerder genoemden, wil ik graag Anke ter Brugge, Annet Janssen, Wim Opstelten, Jannes van Everdingen en Gerda van der Weele bedanken voor hun bijdrage.

Veel dank ook aan het praktijkteam in Gorinchem, mijn directe collega Pieternel Tieleman, collega Douwe de Ruiter, praktijkondersteuners Jessica, Harry en Marja, en assistenten Dinie, Elisabeth, Esther, Florien en Nella. Het is een genot om elke dag om kwart voor acht de praktijk binnen te wandelen en waar te nemen hoe jullie weer zin hebben in de nieuwe dag, fris en opgewekt. Jullie laten zien waar het uiteindelijk allemaal om draait.

Speciale dank aan mijn wielervrienden, onder wie ook een aantal huisartsen. Mannen onder elkaar met uitzondering van Tryntsje, een van de trouwste leden van de groep. Wat is het een genot om elk jaar met jullie te fietsen, door berg en dal. Ik hoop dit nog lang te blijven doen, totdat we erbij neervallen.

Lieve vrienden en familieleden, wij hebben elkaar de laatste jaren te weinig gezien en gesproken. Toch heb ik op de achtergrond jullie warmte en aanwe- 
zigheid gevoeld. Bij mijn schoonfamilie heb ik mij altijd welkom gevoeld en vertrouwd om lief en leed mee te delen. Onder hen zwager en collega Peter, die mijn leven een beslissende wending naar het geluk heeft gegeven. Simone en Marjanne, mijn zussen, dank ik voor hun liefde en rotsvaste vertrouwen in grote broer, en Nils en Geert-Jan, mijn zwagers, voor hun sportieve belangstelling en energieke coaching.

Lieve ma, wat fijn dat jij erbij bent. Samen met pa, die ons te vroeg is ontvallen, heb je mij onvoorstelbaar veel warmte en liefde gegeven. Dit maakt wie ik geworden ben. Vol vertrouwen en optimisme.

Karen, mijn supervrouw, door jou ben ik een completer mens geworden en is er een wereld voor mij opengegaan. Zonder jou had ik hier niet gestaan. Tot slot mijn prachtige dochters, Femke en Lotte. Wat ben ik trots op jullie, zoals jullie in het leven staan en ervan genieten. Dat maakt mij ongelofelijk blij!

Ik heb gezegd. 


\section{Literatuur}

1. AGREE Collaboration. Development and validation of an international appraisal instrument for assessing the quality of clinical practice guidelines: the AGREE project. Qual Safe Health Care 2003;12:18-23.

2. Advies- en expertgroep Kwaliteitsstandaarden (AQUA). Leidraad voor Kwaliteitsstandaarden. Diemen: Zorginstituut Nederland, 2015.

3. Barclay WR. Consensus Development Conferences. JAMA 1978;240:378-9.

4. Berntsen GKR, Gammon D, Steinsbekk A, et al. How do we deal with multiple goals for care within an individual patient trajectory? A document content analysis of health service research papers on goals for care. BMJ Open 2015;5:e009403.

5. Boivin A, Currie K, Fervers F, Gracia J, James M, Marshall C, et al; on behalf of G-I-N PUBLIC. Patient and public involvement in guidelines: international experiences and future perspectives. Qual Saf Health Care 2010;19:e22.

6. Boivin A. Patient and public involvement in healthcare improvement [proefschrift]. Nijmegen: Radboudumc, 2012.

7. Burgers JS. NHG-Standaarden en de invloed van evidence-based medicine. In: Geijer RMM, Burgers JS, Van der Laan JR, Wiersma Tj, Van der Laan JR, Rosmalen CFH, Thomas S. NHG-Standaarden voor de huisarts I (2e geheel herziene druk). Utrecht: NHG, 1999.

8. Burgers JS, Van Everdingen JJE. Evidence-based richtlijnontwikkeling: het EBRO-platform. Ned Tijdschr Geneeskd 2004a;148:2057-9.

9. Burgers JS, Van Everdingen JJE. Beyond the evidence in clinical guidelines. Lancet 2004b;364:392-3.

10. Burgers JS. Van reductionisme naar realisme: opschudding over evidencebased medicine en de gevolgen voor richtlijnen. Ned Tijdschr Geneeskd 2015;159:A8376.

11. Damoiseaux RAMJ. 'Personalised care' in richtlijnen: een contradictio in terminis. Ned Tijdschr geneeskd 2014;158:A7408.

12. Daniëls R, Vogelzang F, Den Boer J. Handreiking Gezamenlijke besluitvorming over doelen en zorgafspraken, in opdracht van Zorginstituut Nederland, 2016.

13. De Booys M, Nederkoorn A. Notitie cliënteninbreng en het Kwaliteitsinstituut. Zorginstituut Nederland, 2015.

14. De Wit M, Abma T, Koelewijn-van Loon M, Collins S, Kirwan J. Involving patient research partners has a significant impact on outcomes research: a responsive evaluation of the international OMERACT conferences. BMJ Open 2013;3(5). 
15. Díaz Del Campo P, Gracia J, Blasco JA, Andradas E. A strategy for patient involvement in clinical practice guidelines: methodological approaches. BMJ Qual Saf 2011;20:779-84.

16. Every-Palmer S, Howick J. How evidence-based medicine is failing due to biased trials and selective publication. J Eval Clin Pract 2014;20:908-14.

17. Fretheim A, Schünemann HJ, Oxman AD. Improving the use of research evidence in guideline development: 3 . Group composition and consultation process. Health Res Policy Syst 2006;4:15.

18. Gezondheidsraad. Onderzoek waarvan je beter wordt: een heroriëntatie op umc-onderzoek. Den Haag: Gezondheidsraad, 2016.

19. Goudswaard AN, In 't Veld CJ, Dijkstra R. Van richtlijnen, de dingen die niet voorbijgaan. Huisarts Wet 2010;53:51-4.

20. Grahame-Smith D. Evidence-based medicine: Socratic dissent. BMJ 1995;310:1126-7.

21. Greenhalgh T. Narrative based medicine in an evidence based world. BMJ 1999;318:323.

22. Greenhalgh T, Howick J, Maskrey N, the Evidence Based Medicine Renaissance Group. Evidence based medicine: a movement in crisis? BMJ 2014;348:g3725.

23. Grol R. Implementing guidelines in general practice care. Qual Health Care 1992a;1:182-91.

24. Grol R, Heerdink H. De bekendheid met en acceptatie van standaarden onder huisartsen. Een longitudinale analyse. Huisarts Wet 1992b;35:101·4.

25. Grol R, Wensing M. Implementatie: effectieve verbetering van de patiëntenzorg (zesde, herziene druk). Houten: Bohn Stafleu Van Loghum, 2015.

26. Guyatt GH, Oxman AD, Vist GE, Kunz R, Falck-Ytter Y, Alonso-Coello P, Schünemann HJ; GRADE Working Group. GRADE: an emerging consensus on rating quality of evidence and strength of recommendations. BMJ 2008;336:924-6.

27. Huygen FJA. NHG, Quo vadis? Huisarts Wet 1959;2:187-91.

28. KNAW, KNMG, GR, CBO, NHG, OMS. Code ter voorkoming van oneigenlijke beïnvloeding door belangenverstrengeling, 2012. Beschikbaar via: www. knaw.nl/nl/actueel/publicaties/code-ter-voorkoming-van-oneigenlijkebeinvloeding-door-belangenverstrengeling.

29. Légaré F, Boivin A, Van der Weijden T, Pakenham C, Burgers J, Légaré J, et al.. Patient and public involvement in clinical practice guidelines: a knowledge synthesis of existing programs. Med Decis Making 2011;31:E45-74.

30. National Research Council. Toward Precision Medicine: Building a Knowledge Network for Biomedical Research and a New Taxonomy of Disease. Washington: The National Academies Press, 2011. 
31. Polanyi, M. The Tacit Dimension. London: Routledge, 1966.

32. Popper K. The Logic of Scientific Discovery. London: Hutchinson \& Co, 1959.

33. Pagliari C, Grimshaw J, Eccles M. The potential influence of small group processes on guideline development. J Eval Clin Pract 2001;7:165-73.

34. Raine R, Sanderson C, Black N. Developing clinical guidelines: a challenge to current methods. BMJ. 2005;331:631-3.

35. Richards T, Montori VM, Godlee F, Lapsley P, Paul D. Let the patient revolution begin. BMJ 2013;346:f2614.

36. Rutten GEHM, Thomas S, redactie. NHG-Standaarden voor de huisarts. Utrecht: Wetenschappelijke uitgeverij Bunge, 1993.

37. Sackett DL, Richardson WS, Rosenberg W, Haynes RB. Evidence-based medicine. How to practice and teach EBM. New York: Churchill Livingstone, 1997.

38. Scholten RJPM, Offringa M, Assendelft WJJ. Inleiding evidence-based medicine: klinisch handelen gebaseerd op bewijsmateriaal. Houten: Bohn Stafleu van Loghum, 2014.

39. Stolper E. Gut feelings in general practice [proefschrift]. Maastricht: Universitaire Pers Maastricht, 2010.

40. Thomas S. Standaarden van het Nederlands Huisartsen Genootschap. Ned Tijdschr Geneeskd 1993; 42: 2135-8.

41. Thomas S, Geijer RMM, Van der Laan JR, Wiersma Tj, redactie. NHG-Standaarden voor de huisarts II. Utrecht: Wetenschappelijke Uitgeverij Bunge, 1996.

42. Van de Bovenkamp H. The limits of patient power: examining active citizenship in Dutch health care [proefschrift]. Rotterdam: Erasmus Universiteit Rotterdam, 2010.

43. Van der Weijden T. Richtlijnen in de spreekkamer, van dogma naar dans. Inaugurele rede. Maastricht, 2010.

44. Van der Weijden T, Boivin A, Burgers J, Schünemann HJ, Elwyn G. Clinical practice guidelines and patient decision aids. An inevitable relationship. J Clin Epidemiol 2012;65:584-9.

45. Van derWeijden T, Pieterse AH, Koelewijn-van Loon MS, Knaapen L, Légaré F, Boivin A, et al. How can clinical practice guidelines be adapted to facilitate shared decision making? A qualitative key-informant study. BMJ Qual Saf 2013;22:855-63.

46. Van Esch, T, Mullenders P, Brabers A, Hek K, De Jong J. De rol van patiënten bij het afwijken van richtlijnen door huisartsen. Een onderzoek naar het voorschrijven van antibiotica. Utrecht: NIVEL, 2016. 
47. Van Everdingen JJE. Preventie van diep veneuze trombose en longembolie; een verslag van de Amerikaanse consensusbijeenkomst. Ned Tijdschr Geneeskd 1986;130:1369-70.

48. Van Everdingen JJE. Consensusontwikkeling in de geneeskunde [proefschrift]. Utrecht, 1988.

49. Van Everdingen JJE, Dreesens D, Burgers JS, Swinkels JA, Van der Weijden T, Van Barneveld TA (red). Evidence-based richtlijnontwikkeling. Een leidraad voor de praktijk (tweede druk). Houten: Bohn Stafleu Van Loghum, 2014.

50. Wennberg JE, Gittelsohn A. Health Care Delivery in Maine I: Patterns of Use of Common Surgical Procedures. J Maine Med Assoc 1975;66:123-30,149.

51. Wiersma Tj. Twee eeuwen zoeken naar medische bewijsvoering. De gespannen verhouding tussen experimentele fysiologie en klinische epidemiologie [proefschrift]. Amsterdam: Boom/Belvédère, 1999.

52. Wiersma Tj, Burgers JS. Kanttekeningen bij het gebruik van 'levels of evidence' in richtlijnen. Huisarts Wet 2002;45:610-2.

53. Wollersheim H. Beyond the evidence of guidelines. Neth J Med 2009;67:3940 .

54. Zorginstituut Nederland. Leidraad voor ontwikkelen van patiënteninformatie en keuzehulpen bij kwaliteitsstandaarden in de curatieve zorg. December 2016.

55. Zuiderent-Jerak T, Forland F, Macbeth F. Guidelines should reflect all knowledge, not just clinical trials. BMJ 2012;345:e6702. 




\section{Kernboodschappen}

- Persoonsgerichte zorg vraagt om gerichte toepassing van beschikbare kennis met richtlijnen als leidraad.

- Richtlijnen vormen een betrouwbare basis van de geneeskunde, mits samengesteld op basis van wetenschappelijke literatuur, breed gedragen professionele expertise en relevante patiëntervaringen.

- Richtlijnen ondersteunen het proces van klinische besluitvorming door de beleidsopties en afwegingen expliciet te maken voor de arts én de patiënt.

- Richtlijnen zijn er niet om blind opgevolgd te worden, maar om weloverwogen te gebruiken als hulpmiddel bij het leveren van persoonsgerichte zorg in de praktijk.

Het Nederlands Huisartsen Genootschap (NHG) heeft in juni 2016 de NHG-leerstoel 'Promoting Personalised Care in Clinical Practice Guidelines' ingesteld. Het NHG wil hiermee bijdragen aan de wetenschappelijke ontwikkeling van kennis en innovatie op het gebied van richtlijnontwikkeling. Deze leerstoel biedt huisarts en bijzonder hoogleraar Jako Burgers de mogelijkheid om wetenschappelijk onderzoek en scholing te stimuleren en te ontwikkelen.

De leerstoel is ondergebracht bij de vakgroep Huisartsgeneeskunde, onderdeel van CAPHRI (Care and Public Health Research Institute) van de Faculty of Health, Medicine and Life Sciences van de Universiteit Maastricht. Inbedding in CAPHRI geschiedt binnen het programma 'Promoting Health and Personalised Care'. 